\title{
THE SOCIAL IMPACT TOWARD A NORTH CAROLINA MAN AS SEEN IN NICHOLAS SPARKS' THE NOTEBOOK
}

\author{
SITI MARDA YULIANA ${ }^{1}$ \\ RAFLIS $^{2}$ \\ SILVIA DJONNAIDI ${ }^{3}$
}

\author{
Volume 1 Nomor 1 \\ JILP \\ ISSN: 2581-0804 \\ E-ISSN: 2581-1819
}

\begin{abstract}
The problem in this study is social impact from North Carolina citizen for the main character's life. In the novel, Noah's life is influenced by his social life, especially his love story with Allie. They are separated because of the difference of social class and people's view about them who come from different status.

From the result of this study found that, 1) social impact from people around to the main character in The Notebook novel, that is separating social class into three types, low class, middle class and

high class, 2) social impact also influenced by the environment, which is North Carolina has beautiful view and make the people love their hometown by writing the poem, but in other side, environment makes space between people and their social status, 3) social impact is influenced by North Carolina citizen's view who separate people based on the social class, and it makes the interaction between low class and high class is very limited, especially in relationship and marriage.
\end{abstract}

Keywords: social impact, North Carolina, environment, high class, middle class, low class

\begin{abstract}
ABSTRAK
Permasalahan dalam skripsi ini adalah dampak sosial dari masyarakat Carolina Utara terhadap kehidupan tokoh utama. Dalam novel ini, kehidupan Noah sangat dipengaruhi oleh lingkungan sosialnya, terutama kisah cintanya dengan Allie. Mereka harus terpisah karena status sosial mereka yang berasal dari strata yang berbeda.

Dari hasil penelitian dapat ditemukan bahwa, 1) dampak sosial masyarakat terhadap tokoh dalam novel The Notebook adalah pembagian kelas sosial dalam masyarakat, yaitu kelas atas, kelas

menengah dan kelas bawah, 2) dampak sosial juga dipengaruhi oleh lingkungan, dimana Carolina Utara memiliki alam yang indah yang membuat masyarakatnya sangat mencintai daerahnya dengan mencipatakan puisi, tapi di sisi lain, lingkungan menciptakan jarak antara masyarakat dan kelas sosialnya, 3) dampak sosial dipengaruhi oleh pandangan masyarakat yang membedakan masyarakat berdasarkan pada status sosialnya, sehingga interaksi antara kelas atas dan kelas bawah sangat dibatasi, terutama dalam hal hubungan dan pernikahan.
\end{abstract}

Kata Kunci: dampak sosial, Carolina Utara, lingkungan, kelas atas, kelas menengah, kelas bawah 


\section{INTRODUCTION}

The Notebook tells about social impact on The North Carolina citizen, in this case Allie and Noah. Allie had spent fourteen years in fear of hurting her family and friends if she deviated from the standard way of living for her social class. It was only when she realized that she and Noah were meant to be together that she made the right decision and followed her heart. Noah was convinced that they were soul mates who had lived many lives looking for each other, sometimes finding each other and sometimes not.

From the novel, can be found that Allie as the main character would always make a mistake if she failed to recognize Noah as the one she was meant to be with for eternity. First, they must face the pressures of her parents and their social position. Her mother hid his letter to her and even pressured her to give up painting, a talent that Noah had encouraged. Second, they face the pressures of fourteen years in which Noah is shaped by his father and his desire to escape his loss of her. Third, they face her engagement to Lon Hamilton who comes from an influential and important family.

The story between Allie and Noah that described in the novel is something taboo for doing at that time, where they live in North Carolina which always hold on their culture and social status.

\section{REVIEW OF RELATED THEORIES}

The analysis needs some important concepts and theories that related to the problem in order to help the analysis then the whole concepts will be stated as theoretical framework. As Stryker states that:

"...a theory is a framework for understanding things about the world in which we live e.g. physical, economic, spiritual or social (1985:45)".

\section{SOCIOLOGICAL APPROACH}

The condition such as physical, economic, spiritual or social are influenced by society. For this reason, the sociological approach is applied for this analysis. According to Stryker states that: "Sociological approach to understand the self and its parts (identities) means that we must also understand the society in which the self is acting and keep in mind that the self is always acting in a social context in which other selves exist (1990:2)"

It means that the certain people are actually having interaction with is environment which comprise of a group of society and they will be affected by society they can act, understand and feel everything in social context.

Sociological approach concerns toward society therefore when the people want to understand the self or the individual's life the people need to know the society where the individual was living. Since the individual life appear as the reflection of society. Wellek and Warren present three perspectives of sociology literature relationship including the sociology of the author, the social context of the literary works and the literature's influence on society (Wellek and Warren, 1956:96).

The sociology of the author deals with the life story of the author which includes social status and another factors related to the author who creates literary work. The relationship sociology and literature exist since literary works is written by the author. Then, the author himself is the member of the society where both of them are not apart. Thereby, the behaviors of individuals will create a group, organizations and networks therefore we will know how a person's life which is actually part of society. Yohanda state that:

"Sociology is the scientific study of human behavior. It shows us how the people interact with each other, how groups and societies differ and how social affect human behaviors" (2005:19).

Sociological approach is an approach which is used to study about human behavior. Especially their interaction in a group and social community. Each individual is actually part of society.

A. Society

A society is a group of people involved in persistent social interaction or a large social grouping sharing the same geographical or social territory, typically subject to the same political authority and dominant cultural expectations. Societies are characterized by pattern of relationship (social relations) between individuals who share a distinctive culture and institutions; a given society may be described as the sum total of such relationship among its constituent members. In the social science, a larger society often evinces stratification or dominance patterns in subgroups. Insofar as it is collaborative, a society can enable its members to benefit in ways that would not otherwise be 
possible onan individual basis; both individual and social (common) benefits can thus be distinguished or in many cases found to overlap.

A society can also consist of like-minded people governed by their own norms and values within a dominant, larger society. This is sometimes referred to as a subculture, a term used extensively within criminology. More broadly, and especially within structural thought, a society may be illustrated as an economic, social, industrial or cultural infrastructure, made up of, yet distinct from, a varied collection of individuals. In this regard society can mean the objective relationship people have with the material world and with other people, rather than "other people" beyond the individual and their familiar social environment.

Society, in generals, addresses the fact that an individual has rather limited means as an autonomous unit. Societies are most often organized according to their primary means of subsistence. Social scientist have identified hunter-gatherer societies, nomadic pastoral societies, horticulturalist or simple farming societies and intensive agricultural societies and post-industrial societies to be qualitatively different from traditional agricultural society.

\section{B. Character}

All stories must have certain characteristics or elements. Without these elements, any piece of literature would cease to make sense or serve a purpose. For example, stories must have a plot, or events that take place. Another essential story element is the character. Character can be defined as any person, animal, or figure represented in a literary work. There are many types of characters that exist in literature, each with its own development and function.

The general purpose of characters is to extend the plot. Many stories employ multiple types of characters. Every story must have main characters. These are the characters that will have the greatest effect on the plot or are the most affected by what happens in the story. There are many ways to categorize main characters: protagonist or antagonist, dynamic or static character, and round or flat characters. A character can also often fit into more than one category or move through categories.

Nearly every story has at least one protagonist. A protagonist is a main character who generates the action of a story and engages the reader's interest and empathy. The protagonist is often the hero or heroine. The protagonist is usually a welldeveloped character; in this way, she is more relatable. The opposite of the protagonist is the antagonist. An antagonist is a character who opposes the protagonist. Together, the protagonist or protagonists and antagonist or antagonists move the plot along, create the action, and draw the reader's interest.

C. Plot

The plot of a story consists of the events that occur during the course of that story and the way in which they are presented to the reader. The plot is also sometimes referred to as the storyline.

There are five main elements in a plot. The first is the exposition or the introduction. This is known as the beginning of the story where characters and setting are established. The conflict or main problem is introduced as well. The second element of a plot is known as the rising action which occurs when a series of events build up to the conflict.The main characters are established by the time the rising action of a plot occurs and at the same time, events begin to get complicated. It is during this part of a story that excitement, tension or crisis is encountered. The third element of a plot is known as the climax or the main point of the plot. This is the turning point of the story and is meant to be the moment of highest interest and emotion. The reader wonders what is going to happen next. The fourth element of a plot is known as falling action or the winding up of the story. Events and complications begin to resolve and the result of actions of the main characters are put forward. The last element of a plot is the resolution or the conclusion. It is the end of a story and ends with either a happy or a tragic ending.

D. Setting

Setting is the place and condition in which something happens or exists. In literary work, setting can be separated into two kind of setting. Setting is an environment or surrounding in which an event or story takes place. It may provide particular information about placement and timing, such as New York, America, in the year 1820 . Setting could be simply descriptive like a lonely cottage on a mountain. Social conditions, historical time, geographical locations, weather, immediate surroundings, and timing are all different aspects of setting. It has its three major components; social environment, place and time. Moreover, setting could be an actual region, or a city made larger than life, or it could be a work of imagination of the author. 


\section{METHOD OF THE RESEARCH}

Methodology is science that learns about methods, procedures and technique of research (Harsono, 2006:6). Methodology is one of important parts in doing research. Some methods are used to conduct the research. Those are data and data source, method of collecting data, method of analysis data, technique of collecting data and technique of analysis data. The object of this study is social impact in North Carolina. The data comes from the content of The Notebook novel written by Nicholas Sparks. The Notebook novel is the main data, and the expert book in literature, methodology research, sociological and society are the supporting data.

The method of collecting data uses library research. This research is oriented in the library in order to find the related data, however it is not restricted in finding other written material from internet or even from the motion picture. A library is a collection of sources of information and similar resources, made accessible to a defined community for reference or borrowing. It provides physical or digital

\section{FINDING AND ANALYSIS}

\section{A. The Society in North Carolina}

There are three main characters that represent the society of North Carolina: Noah as the low class character, Allie as the high class character, and Lon as the working class character. The main character, Noah, comes from the low class, it meant that society looks down on him and he has no chance of having relationship with the high class woman, Allie. The position of Noah as the low class of North Carolina society can be seen in the following: I'm nothing special, of this I'm sure. I am common man with common thoughts and I've led a common life. There are no monuments dedicated to me and my name will soon be forgotten, but I've loved another with all my heart and soul, and to me, this has always been enough (page 1).

The first character, Noah falls in love with Allie the summer after graduating from high school, and even though they go their separate ways, he never stops loving her. When she unexpectedly re-enters his life, he discovers she is engaged. Although he longs for Allie to stay and tells her that, he knows that loving someone sometimes means letting them go. The second access to material, and may be a physical building or room, or a virtual space, or both.

The method that used in analysis this study is dynamic structuralism method. The method used in order to see the relationship between literary work and society. Dynamic structuralism is a general approach to development that views psychological structure as the dynamic organization of self-constructed, socially embedded skills and activities.

Technique of collecting the data method is folding the important pages which consist of the problem that will be analysis in study. Then, underlining and making a note for the main data that related to the problem which will be analysis by using some theories, concept and approach. These techniques are used to help easier in analysis later. The main data are taken from the comprehension of narrative, dialogues and thinking of the author which is stated in narrative of The Notebook.

The technique which used in analysis data is interpreting the data and analyze the data based on theory and concept.

character, Allie, As a young woman she falls in love with Noah, a boy beneath her family's social class; when Allie per chance sees a newspaper article about Noah restoring a house, she needs to return to see her summer love, even though she is engaged to another. Allie falls in love all over again and then must make a decision between the two men that she loves, and although she does not want to hurt either one, inevitably, she will. The Third character, Lon as Allie's fiancé; Lon is a good lawyer from a good family who will provide a good life for Allie. When he realizes that Allie is seeking out Noah, he drops everything to be with her, demonstrating for the first time that he is able to put her ahead of his career. First, Noah character, Noah is the main character (protagonist) of The Notebook. He is the hero. Noah represents true love, true faith, and true artistry. In one sense, The Notebook is similar to a medieval morality play, and Noah is a contemporary "Everyman." The characters in a morality play were symbolic representations used to illustrate an idea; Noah represents true, faithful, committed love. Noah remains true to Allie even when he does not know if he will ever even see her again. 
In many regards, Noah is the ideal man, he is faithful, idealistic, strong, good looking, a poet, and helpful to those in need. The Noah of the main narrative is almost too good to be true. $\mathrm{He}$ has a strong relationship with family and friends and is respectful to both nature and authority. He seemingly has no faults.

The Noah of the frame story is older yet still exhibits the same characteristics; he is also loyal, faithful, committed, strong, and realistic. The dedication he demonstrates to both his wife and the other residents of the extended care facility is utterly amazing.

Finally, Noah can be seen as a symbol for Nicholas Sparks himself, and The Notebook, which is dedicated to his wife, who is his best friend, is Sparks' own love story. The story inspired by Cathy's grandparents is one long love letter from the man who truly seems to be practicing what he preaches.

Second, Allie character, Allie wants the best of both worlds as she represents the different types of love that exist. In essence she is the embodiment of a thematic topic. As Allie grows and matures, so does her understanding of love. Her growth symbolizes the development of real love, from a potential summer fling through a tough decision to a career-creating relationship that yields children who are the product of that committed love.

They didn't agree on much. In fact, they rarely agreed on anything. They fought all the timeand they challenged each other every day. But despite their differences, they had one important thing in common: They were crazy about each other (page 59).

Her relationship with Noah reveals the essence of true love, where one is able to develop one's own talents, skills, and abilities. Allie is able to develop as an artist, and a character, because of Noah's love for her. Yet, she is not dependent solely on Noah, for she makes important decisions, she chooses to seek him out, she chooses him over Lon, and she chooses to write an emotional an insightful letter to Noah in order help him deal with her illness.

Third, Lon character, Lon is the stereotypical, self-obsessed individual who realizes too late that his self-absorption is going to cost him his fiancée. Lon is also the embodiment of the conflict in The Notebook. As a character, he is the one readers know as the obstacle to Allie's love. He is a dynamic character, but his change is a little too late.
Lon calls from his office because staying late is standard for him, which reveals how important his career is to him, but it also offers a partial explanation for Allie's actions. If Lon puts his career ahead of his fiancé, then Allie has time to ponder her past and rethink her commitment to the relationship. Lon focuses on himself and his own needs, but his willingness to call Allie multiple times indicates that he is both concerned for her wellbeing as well as concerned about the implications this trip may have on their relationship. Although he may have been taking her for granted, Lon loves Allie.

Lon is obviously scared about what he might lose, but the more important question must be, "Is Lon more scared of losing Allie or more scared about what might happen to him?" The difference between these two extremes is immense, one focuses on Allie and the other on Lon. Readers are not currently privy to Lon's thoughts and motivations, yet the two possible interpretations of his state of mind illustrate the difference between being loved and loving another, two important thematic topics in The Notebook. Although this chapter is a short one, it is significant because it provides a contrast to the romantic reunion of the previous chapter as well as foreshadows the conflict yet to come.

Then, as the character Noah explains in the beginning of The Notebook, this is a tragic love story. The tragedy comes in the later years of the characters' lives, as Allie can no longer remember who Noah is. This is painful for Noah and frightening for Allie. However, the expression of their love is so powerful that even the effects of Alzheimer's cannot keep every memory of love submerged in the depths of forgetfulness. Doctors cannot explain how every once in a while, Allie suddenly recognizes Noah, even in the later stages of the disease. The nurses at the home, however, are fully aware of how this is so. They see the love in Noah's eyes, in the way he patiently tends to his wife, even though she sometimes screams at him to leave her alone because he frightens her. She believes Noah is a stranger, at times, and the doctors make Noah leave the room.

The author paints a beautiful picture of the passion that these two characters share as they face the challenges that try to keep them apart. Readers witness Allie and Noah's wild emotions as they first taste their love as well as the quieter moments in later years when all they have to do is gently grasp one another's hands to express how deeply they feel about one another. 
B. The Environment's Effect on North Carolina Citizen

The environment determines the North Carolina Citizen, the beautiful scenery of North Caroline has inspired the people to create beautiful poem, as in the novel of The Notebook, there are many poems in the story about love.

It was early October 1946, and Noah Calhoun watched the fading sun silk lower from the porch of his plantation-style home. He especially liked to look at the trees and reflections in the river. North Carolina trees are beautiful in deep autumn: greens, yellows, oranges, every shade in between, their dazzling colors glowing with the sun (page 3).

One of the most important symbols in the novel, the Walt Whitman collection of poems called Leaves of Grass, is introduced in this chapter. The old book with a torn cover reveals the importance of the book for Noah. Although knowledge of this poetry collection is not essential to an understanding of The Notebook, it does serve as an important allusion. Readers familiar with Whitman's seminal text and its importance to the development of Whitman as an artist will gain significant insight into Noah's character.

The poem to which Noah refers is "A Clear Midnight," a poem that illustrates both Whitman's and Noah's tender side. The poem moves from the individual to the greater world, moving outward like a prayer. This poem is one long sentence, expressing the paradox of compression and expansion all in one. Clearly the speaker of the poem symbolizes Noah, and the apostrophe to the Soul creates a spirituality that exists within him. The Soul foreshadows the idea of soul mates, and by the end of the chapter, Allie is clearly Noah's soul mate.

The poem "A Clear Midnight" is not merely emotional, nor is it merely intellectual. But definitely, it is spiritual. The connection between the speaker of the poem and his soul mirrors the connection that Noah has, albeit yet unknown to new readers, with Allie.

Leaves of Grass is the poetry collection that Walt Whitman spent his entire life editing, rewriting, and adding to. Whitman was heavily influenced by transcendentalism and the romanticism that inspired it, thus indicating forms and influences of particular importance to Nicholas Sparks and The Notebook.
This is thy hour, o Soul, thy free flight into their wordless,

Away from hooks, away from art, the day erased, the lesson done,

Thee fully forth emerging, silent, gazing, pondering the themes,

Thou lovest best,

Night, sleep, death and the stars. (page 5)

Noah is connected with poets and poetry. In fact, the narrator specifically states that "isolation ... was good for the soul," an idea that poets understood, as did Noah. The continued comparison of Noah to a poet is the most important and sustained bit of character development in The Notebook.

Poets often describe love as an emotion that we can't control, one that overwhelms logic and common sense. That's what it was like for me. I didn't plan on falling in love with you, and I doubt if you planned on falling in love with me. But once we met, it was clear that neither of us could control what was happening to us (page 59).

A poet is an artist and a dreamer and a person connected with nature and spirituality. And the poets with whom Noah is connected further develop his character as they reveal information about his attitudes and beliefs.

The mention of Tennyson immediately brings to mind such poems as "Break Break Break," a poem inspired by the British Romantic period and "Ulysses," a dramatic monologue from the hero of The Odyssey longing for something more before his death. The reference to Dylan Thomas immediately connects Noah to Thomas' most famous poem, "Do Not Go Gentle into that Good Night." The poem, a villanelle, is essentially an argument for fighting death, primarily to give closure to life by living life to the fullest until it is over. In the context of The Notebook, the life to which "Do Not Go Gentle" refers is the love between Noah and Allie.

The poem is a symbolic imperative that commands Noah and Allie to fight for their love before they die, a command that foreshadows important events in the final chapter of The Notebook.

Nicholas Sparks transcends the form of a typical romance novel through his use of literary allusions. He develops characters and themes about the universality of the human experience of love and loss and fate and free will, rather than 
writes a story about reunited lovers and their hopes to rekindle past romantic flames. Although readers do not need to understand the allusions to understand the basic plot and themes of The Notebook, an appreciation of the seemingly insignificant references provides another layer of understanding of the sophistication of the text.

Allie remembers lines from "Song of Myself," one of the poems Noah reads to her during their summer of love. "Song of Myself," one of the poems from Leaves of Grass, explores notions of the self and the relationship that oneself has with nature. "Song of Myself" states, paradoxically, that the self is both individual as well as universal. The poem is about sexual and spiritual union, obviously symbolizing the nature of the relationship between Noah and Allie, reiterating that their summer romance was not one of teenage lust but rather one of young adults falling deeply in love.

The chapter ends with the narrator echoing Gus' earlier sentiments that Allison is the ghost that has been haunting Noah, yet the title of the chapter is "ghosts," indicating that Noah is also a ghost for Allison.

The narrative not only switches from Allie's day to Noah's day (and back again), until the moment when their two separate stories once again combine, it also toggles between past and present, creating for the reader a sense of memory and re-memory. Sparks uses this technique to fulfill the four equally important purposes of the chapter: to provide exposition, to build suspense, to introduce the main characters, to introduce the primary conflict.

When explaining his answer to Allie's question about his summer memories, Noah describes love "as an emotion that we can't control, one that overwhelms logic and common sense." For him, this describes both their summer of love and the nature of their relationship.

The mentioning of T.S. Eliot reveals yet another side of Noah's character. As a poet, Eliot is more abstract and intellectual than Whitman. Eliot's most famous poem is the epic The Waste Land, which could be a veiled reference to the state of Noah's emotional well being. An important aspect of Noah and Allie's relationship is made clear when readers learn that Lon did not understand Allie's abstract painting. Lon clearly does not understand the depths of Allie's passion and soul, whereas, Noah encourages Allie to develop her own gifts and passions. This demonstrates that Noah has a connection with and an understanding of Allie as a person and an artist, a connection and understanding that is currently missing in Allie's life.

C. North Carolina Citizen's View About Life's Influence

North Carolina citizen's view about life's influence can be seen from narration about the difference of status between Noah and Allie, between low class status and high class status, the view that sees social class as the respect in life. The high class people are ashamed to marry with the low class people.

The main storyline is the reunion of Noah and Allie and the conflict that they face as they must decide the path their lives will now take. This particular event only lasts three days in 1946; however, important information that shapes their reunion occurred weeks and years earlier. If you imagine a picture in a frame, the reunion is the photograph. And the opening and closing chapters of the novel are set in the present, some 49 years later. The present-day storyline frames the reunion story.

The reason it hurts so much to separate is because our souls are connected. Maybe they always have been and will be. Maybe we've lived a thousand lives before this one and in each of them we've found each other. And maybe each time, we've been forced apart for the same reasons. That means that this goodbye is both a goodbye for the past ten thousand years and a prelude to what will come (page 80).

Although the frame represents the present and current storyline and the picture represents the reunion, within these two main storylines are other stories, some are episodes and others are vignettes, which are told in the form of a flashback. These stories, told within the context of the other storylines, fit within both the picture and the frame. And some of these smaller stories of earlier events frame even smaller stories of other events. Each story is distinct within itself while simultaneously being an integral part of a greater whole; every individual picture is a part of a bigger picture.

This framework technique provides the structure of the plot, and flashback is the technique Sparks uses to tell the stories. Characters reveal these "framed" stories through their shared and private memories. Often the reader shares a flashback with a character that is not shared with any other character.

The narrator also provides information. The narrator of The Notebook in the opening and 
closing chapters is Noah. But the narrator of the middle chapters provides a limited, third-person omniscient point of view. This perspective sometimes allows the readers into the mind of a character, typically Noah and Allie, but sometimes does not, such as Anne and Lon. This technique is important because it allows the storyline to flow seamlessly from past to present and back again.

Stylistically, the narrative techniques work well because The Notebook is not just a love story; the novel also explores the nature of fate and free will and the way people interact with one another. The intricacies of relationships parallel the intricacies of poetry and the framing technique enables Sparks to weave the past together with the present, leading to the emotional climax and creating a compelling read along the way.

Over the centuries, people have pondered the influence of divine or diabolical power, environment, genetics, even entertainment, as determining how free any individual is in making moral choices. The ancient Greeks acknowledged the role of Fate as a reality outside the individual that shaped and determined human life. In modern times, the concept of fate has developed the misty halo of romantic destiny, which is how fate is viewed in The Notebook.

After spending just one summer together and then not being able to contact one another for fourteen years, the article spotting could be coincidence. Or it could be fate. Regardless of how that specific incident is viewed, Allie still has the power to act on her knowledge and feelings. She chooses to seek out Noah. She chooses to spend the evening and the next day (and the next night) with him. And she chooses to break off her engagement with Lon. The reader cannot know, nor speculate, the events that do not transpire outside the pages of The Notebook, but you can analyze what does occur. We fell in love, despite our differences, and once we did, something rare and beautiful was created. For me, love like that has only happened once, and that's why every minute we spent together has been seared in my memory. I'll never forget a single moment of it (page 59).

Nicholas Sparks, in an interview, stated that as an author, he is "addressing different aspects of love: everlasting love, first love, and second chances at love." These are important themes in all of his novels, and these themes "provide the subtext of the novel in addition to providing the unwritten subtext of the novel that the reader experiences. The subtext, what the author endeavors to show without explanation, gives the novel deeper meaning." Thus, the complex relationship between fate and free will is mirrored in the complex relationship between different aspects of love.

\section{CONCLUSION}

The Notebook is love novel that its popularity and longevity have secured it a place as one of the great romances of all time. The writer then provides the findings from this study:

1. There are three main characters that represents the society of North Carolina: Noah as the class character, Allie as the high class character, and Lon as the working class character.

2. The environment determines the North Carolina Citizen, the beautiful scenery of North

Caroline has inspired the people to create beautiful poem, as in the novel of The Notebook, there are many poems in the story about love.

3. North Carolina citizen's view about life's influence can be seen from narration about the difference of status between Noah and Allie, between low class status and high class status, the view that sees social class as the respect in life. The high class people are ashamed to marry with the low class people. 
Bibliography

Abrams. 1993. The Mirror and The Lamp: Romantic Theory and The Critical Tradition. London: Oxford University Press.

Daiches, David. 1990. Critical Approaches to Literature, Singapore: Singapore Publisher Ltd.

Guerin, Wilfred L. 1992. A Handbook of Critical Approaches to Literature. New York: Oxford University Press,

Hadi, Sutrisno, 1995, Metodologi Penelitian. Yogyakarta: Andi Offset.

Harsono, Siswo. 2006. Metodologi Penelitian Sastra. Semarang: Deaparamtha.

Linda, C. Stanley. 1985. Ways to Writing. Cambridge. University Press

Luxemburg, Jan Van, et.al. 1996. PengantarIlmu Sastra. Jakarta: PT. Gramedia.

Markman, Roberta H., et al. 1992. 10 Steps in Writing the Research Paper. New York: Barron's Educational Series Inc.

Pradopo, Rachmat Djoko, et.al. 2001.
Metodologi Penelitian Sastra. Yogyakarta: PT. Hanindita Graha Widia.

Semi, M. Atar. 1993. MetodePenelitian Sastra. Bandung: Angkasa.

Sparks, Nicholas. 1996. The Notebook. New York: Warner Books, Inc.

Stryker. 1990. Sociology, Human Society, The Sociological Approach. New York: Higher Still.

Stryker, Sheldon and Peter J. Burke. 1985. The past, present, and future of an identity theory. New York: Social Psychology Quarterly.

Wellek, Rene and Austin. 1956. Theory and Literature, New York Harcourt Brace and World Inc.

Yohanda, Asime Lince. 2005. Afro America Dream as Reflected in the Character in Hansberry's A Raisin in the Sun. Unpublished Thesis. Bandar Lampung. Teknokrat. 